\title{
In vivo and in vitro Pathogenesis and Virulence Factors of Candida albicans Strains Isolated from Cutaneous Candidiasis
}

\author{
Golnar Sadeghi ${ }^{1}$, Seyed Fazllolah Mousavi ${ }^{2}$, Mina Ebrahimi-Rad ${ }^{3}$, \\ Esmat Mirabzadeh-Ardekani ${ }^{4}$, Ali Eslamifar ${ }^{5}$, Masoomeh Shams-Ghahfarokhi ${ }^{6}$, \\ Zahra Jahanshiri ${ }^{1}$ and Mehdi Razzaghi-Abyaneh ${ }^{1^{*}}$
}

\begin{abstract}
${ }^{1}$ Department of Medical Mycology, Pasteur Institute of Iran, Tehran 1316943551, Iran; ${ }^{2}$ Department of Microbiology, Pasteur Institute of Iran, Tehran 1316943551, Iran; ${ }^{3}$ Department of Biochemistry, Pasteur Institute of Iran, Tehran 1316943551, Iran; ${ }^{4}$ Department of Medical Biotechnology, Pasteur Institute of Iran, Tehran 13164, Iran; ${ }^{5}$ Department of Clinical Research, Pasteur Institute of Iran, Tehran 13164, Iran; ${ }^{6}$ Department of Medical Mycology, Faculty of Medical Sciences, Tarbiat Modares University, Tehran 14115-331, Iran
\end{abstract}

Received 11 August 2019; accepted 1 October 2019; published online 19 February 2020

\begin{abstract}
Background: The Candida albicans is one of the most important global opportunistic pathogens, and the incidence of candidiasis has increased over the past few decades. Despite the established role of skin in defense against fungal invasion, little has been documented about the pathogenesis of Candida species when changing from normal flora to pathogens of vaginal and gastrointestinal epithelia. This study was carried out to determine the in vivo and in vitro pathogenesis of clinical $C$. albicans strains isolated from skin lesions. Methods: In this study, association of in vivo and in vitro pathogenesis of $C$. albicans isolates with different evolutionary origins was investigated. Oral and systemic experimental candidiasis was established in BALB/C mice. The expression levels of SAP1-3 genes, morphological transformation, and biofilm-forming ability of $C$. albicans were evaluated. Results: All the strains showed in vitro and in vivo pathogenicity by various extents. The SAP1, SAP2, and SAP3 genes were expressed in $50 \%, 100 \%$, and $75 \%$ of the strains, respectively. The biofilm formation ability was negative in $12 \%$ of the strains, while it was considerable in $38 \%$ of the strains. Fifty percent of the strains had no phospholipase activity, and no one demonstrated high level of this pathogenesis factor. Relatively all the strains had very low potency to form pseudohyphae. Conclusion: Our findings demonstrated that Candida albicans strains isolated from cutaneous candidiasis were able to cause oral and systemic infections in mice, so they could be considered as the potential agents of life-threatening nosocomial candidiasis in susceptible populations. DOI: 10.29252/ibj.24.5.319
\end{abstract}

Keywords: Candida albicans, Experimental candidiasis, in vivo pathogenicity, Virulence factors

Corresponding Author: Mehdi Razzaghi-Abyaneh

Department of Mycology, Pasteur Institute of Iran, Tehran 1316943551, Iran; Tel.: (+98-21) 64112804; E-mail: mrab442@yahoo.com or

E-mail: mrab442@pasteur.ac.ir

\section{INTRODUCTION}

$\mathrm{T}$ he polymorphic fungus Candida albicans belongs to the normal flora of human mucosa and in most individuals is considered as a nonpathogenic commensal. Under certain conditions, C. albicans can, however, cause infection that ranges from superficial, such as cutaneous and oral, to lifethreatening systemic candidiasis. The worldwide incidence of candidiasis has increased over the past few decades, which may be attributable to the increased numbers of immunocompromised patients $^{[1,2]}$. Infection by Candida yeasts has been shown to be endogenous in origin. However, 
nosocomial infections are generally transmitted by the health care staff or relatives' hands, from patient to patient, or even by medical devices ${ }^{[3]}$. Despite the established role of skin in defense against fungal invasion, little has been documented about the pathogenesis of Candida species when invading vaginal and gastrointestinal surfaces. $C$. albicans is the major causative agent of superficial Candida-related infections and causes skin thickening, crusting, inflammation, and erythema ${ }^{[4-6]}$. Although laboratory experiments provide reliable data on the virulence and pathogenesis of Candida-related infections, the data from host-fungal pathogen interaction will be quit important to clarify how the fungus affects the human tissue and invade the skin of various body parts ${ }^{[7,8]}$.

Amongst the rodents, mice are the most widely used animal models for investigating clinical Candida isolates from oral mucosa or systemic candidiasis. Such types of candidiasis have been induced experimentally in outbred and inbred mice strains. The most commonly used inbred mice strains are BALB/ $\mathrm{C}^{[9,10]}$. It assumes that the ability of $C$. albicans to be a pathogen from commensal results from producing various virulence factors. In this relation, the morphological transition between yeast and pseudohyphae (known as dimorphism), production of secretory enzymes i.e. Saps, and phospholipase and formation of biofilm are significant virulence factors contributed to $C$. albicans pathogenesis ${ }^{[11,12]}$.

The present study was designed to evaluate the ability of molecular-typed $C$. albicans strains ${ }^{[13]}$ isolated from skin lesions to induce systemic and oral candidiasis in murine models. In our study, the presumptive relation between in vivo and in vitro pathogenesis and differences in molecular types and evolutionary origin of $C$. albicans isolates were considered.

\section{MATERIALS AND METHODS}

\section{Study population and sample collection}

Eight clinical $C$. albicans isolates, as the cause of cutaneous candidiasis, typed by MLST were studied. A portion of the specimens was inoculated on SDA plates (Merck, Germany) supplemented with chloramphenicol $\left(0.05 \mathrm{gL}^{-1}\right)$ and incubated at $37{ }^{\circ} \mathrm{C}$ for $24 \mathrm{~h}$, to isolate the Candida species. All the isolates were identified by a combination of morphological and biochemical analysis including germ tube formation, chlamydospore formation, carbohydrate assimilation (using the commercial system ID32 C,biomérieux Marcy l'Etoile, France), and CHROMagar Candida screening (CHROMagar Candida, Paris, France).
Species identification was confirmed by internal transcribed spacer sequencing.

\section{Animal model}

Isogenic female BALB/C mice $(n=120$, 6-8 weeks old) were obtained from Pasteur Institute of Iran (Tehran, Iran). The mice were kept in plastic cages, allowed free access to water and maintained on a 12:12 $\mathrm{h}$ light/dark cycle. The temperature and humidity were controlled at $23 \pm 1{ }^{\circ} \mathrm{C}$ and $55 \pm 10 \%$, respectively. A number of 56 mice were divided into eight groups of seven mice with different in vitro pathogenesis for each of the oral and systemic candidiasis. In each experiment, four mice were considered as the negative controls.

\section{Experimental systemic candidiasis}

The mice were challenged by the intravenous injection of an inoculum of $2 \times 10^{7} \mathrm{CFU}$ in $100 \mu \mathrm{l}$ of a yeast suspension from cultures grown on SDA via a 25 -gauge syringe at $37{ }^{\circ} \mathrm{C}$ for $48 \mathrm{~h}$. The mice were observed for seven days, and the mortality was noted. For CFU determination in organ, the mice were sacrificed by cervical dislocation after seven days. Kidneys were aseptically harvested as most of the Candida cells in systemic candidiasis murine models are found in the kidneys ${ }^{[14]}$. Each was divided into equal portions for fungal burden determination and histopathological evaluation. For fungal burden determination, the kidneys were weighed and then homogenized in $1 \mathrm{ml}$ of PBS, and homogenates were serially diluted before plating on SDA. The plates were incubated at $37{ }^{\circ} \mathrm{C}$ for $24 \mathrm{~h}$, and the fungal burden was expressed as the ratio of $\log _{10}$ of $\mathrm{CFU}$ to the organ weight $^{[15]}$.

\section{Experimental oral candidiasis}

The murine model of oral candidiasis was set up according to a formerly described method with some modifications ${ }^{[15,16]}$. Establishment of infection at mucosal sites generally requires treatment with immunosuppressive agents prior to infection. One day before infection, the mice were immunosuppressed by subcutaneous injection of prednisolone $(100 \mathrm{mg} / \mathrm{kg}$ body weight), and the antibiotic tetracycline hydrochloride $(0.83 \mathrm{mg} / \mathrm{ml})$ was dispensed in the drinking water. Before infection, the mice were anesthetized with $100 \mu \mathrm{l}$ of ketamine $(100 \mathrm{mg} / \mathrm{kg}$ of mouse)/xylazine (10 mg/kg of mouse) administered intraperitoneally via intramuscular injection on each femur. The oral cavities of the anesthetized mice were swabbed with a sterilized cotton swab that had been dipped in a cell suspension of each strain of $C$. albicans $\left(2.0 \times 10^{7} \mathrm{CFUs} / \mathrm{ml}\right.$ from cultures grown on 
SDA at $37{ }^{\circ} \mathrm{C}$ for $48 \mathrm{~h}$ ). The mice were sacrificed 72 hours after infection. The tongues were divided into equal portions for fungal burden determination and histopathological evaluation. For fungal burden determination, the tongue was weighed and then homogenized in $1 \mathrm{ml}$ of PBS, and homogenates were serially diluted before plating on SDA. The plates were incubated at $37{ }^{\circ} \mathrm{C}$ for 24 hours, and fungal burden was expressed as the ratio of $\log _{10}$ of $\mathrm{CFU}$ to the organ weight $^{[16]}$.

\section{Histopathological study}

For histopathological analysis, kidneys and tongues were fixed in 4\% paraformaldehyde, fixed with paraffin wax and stained with periodic acid-Schiff.

\section{RNA isolation}

Total RNA from $C$. albicans grown in culture was prepared using the RNeasy RNA isolation system, the Molecular Biology kit (Bio Basic Inc, Canada) according to the manufacturer's instructions and stored at $-70{ }^{\circ} \mathrm{C}$ until use. RNA concentration was measured by the absorbance at $260 \mathrm{~nm}$.

\section{Synthesis of cDNA}

To synthesize the cDNA, PrimeScript First strand cDNA Synthesis Kit (Takara Bio Inc, Japan) was used according to the instructions recommended by the manufacturer.

\section{Real-time PCR}

Real-time PCR was used to quantify tity $r$ the virulence genes (SAP1-3) mRNA levels in our isolates, with $A C T 1$ used as a reference housekeeping gene. The PCR primers for amplification of SAP and ACT1 were previously described by Monroy-Pérez et al. ${ }^{[17]}$ (Table 1). A final volume of $25 \mu \mathrm{l}$, including $12.5 \mu \mathrm{l}$ of SYBER Green Master Mix, $1 \mu$ l of each forward and reverse primer, $2 \mu \mathrm{l}$ of cDNA (20 ng), and $8.5 \mu \mathrm{l}$ of RNase-free water, was used for each reaction. The amplification conditions were performed with an initial denaturation of $95{ }^{\circ} \mathrm{C}$ for 10 minutes, followed by 35 cycles of $20 \mathrm{~s}$ at $95{ }^{\circ} \mathrm{C}, 40 \mathrm{~s}$ at annealing temperature of $58{ }^{\circ} \mathrm{C}$, and $30 \mathrm{~s}$ at $72{ }^{\circ} \mathrm{C}$. The gene expression was evaluated by the $\Delta \mathrm{C}_{\mathrm{T}}$ method using the control gene $(A C T 1)$ to normalize the data. Each reaction was performed in triplicate, and the mean values of relative expression were analyzed for each gene ${ }^{[18]}$. The $C$. albicans ATCC10231 strain was used as a positive control. The strains from our collection, each carrying a different deletion of $S A P$ genes, were used as the negative controls ${ }^{[10]}$.

\section{Virulence factors}

The in vitro biofilm formation of Candida isolates was determined as described by Zago et al. ${ }^{[19]}$. The metabolic activity of the biofilm was measured by crystal violet $(1 \% \mathrm{v} / \mathrm{v})$ assay after 48 hours of incubation. Based on the average OD observed, the isolates were classified into three groups showing: (i) low (OD less than 0.12), (ii) medium (OD of 0.120.20 ), and (iii) high (OD higher than 0.20) biofilmforming. Phospholipase activity was evaluated by the methods mentioned by Tsang et al. ${ }^{[20]}$ and GalanLadero et al. ${ }^{[21]}$. Suspension of $10^{8}$ cell $/ \mathrm{ml}$ was dropped onto each test medium. After 48 hours of incubation at $37^{\circ} \mathrm{C}$, the diameters of the colonies (a) and the diameters of the precipitation zone around the colonies (b) were measured. The production of the enzyme was designated as $\mathrm{Pz}=\mathrm{a} / \mathrm{b}$. The following ranges of activity according to $\mathrm{Pz}$ index were established: high, $\mathrm{Pz}=0.40$; medium, $\mathrm{Pz}=0.41-0.60$; low, $\mathrm{Pz}=0.61-0.80$; very low, $\mathrm{Pz}=0.81-0.99$; none, $\mathrm{Pz}=1$. The $\mathrm{Pz}$ index is a reproducible semiquantitative technique used widely. Pseudohyphae formation was defined as a cell bearing a rounded outgrowth with a length greater than or equal to the diameter of the parent cell, with a constriction at the base. After two hours of cell growth in a liquid medium containing an equal volume of RPMI 1640

Table 1. Primers used in real-time PCR assay

\begin{tabular}{lclc}
\hline Gene & Primers & Sequences $\left(5^{\prime}-3^{\prime}\right)$ & $\begin{array}{c}\text { Size of amplified } \\
\text { product (bp) }\end{array}$ \\
\hline \multirow{2}{*}{ SAP1 } & SAP1F & TCAATCAATTTACTCTTCCATTTCTAACA & 161 \\
& SAP1R & CCAGTAGCATTAACAGGAGTTTTAATGACA & \\
SAP2 & SAP2F & AACAACAACCCACTAGACATCACC & 178 \\
& SAP2R & TGACCATTAGTAACTGGGAATGCTTTAGGA & \\
\multirow{2}{*}{$S A P 3$} & $S A P 3 \mathrm{~F}$ & CCTTCTCTAAAATTATGGATTGGAAC & 231 \\
& $S A P 3 \mathrm{R}$ & TTGATTTCACCTTGGGGACCAGTAACATTT & \\
\multirow{2}{*}{$A C T 1$} & $A C T 1 \mathrm{~F}$ & GACCGAAGCTCCAATGAATC & 181 \\
\hline
\end{tabular}


(Sigma, USA) and fetal bovine serum (GIBCO, USA), the percentage of cells in pseudohyphae form against blastopores was determined by microscopy, counted as described by Negri et $a l^{[22]}$.

\section{Statistical analysis}

Results were analyzed using the Graph Pad Prism 6. One-way ANOVA and Unpaired $t$-test were used for the statistical analysis. $p$ values $<0.05$ were considered statistically significant.

\section{Ethical statement}

The above-mentioned sampling/treatment protocols were approved by the Institutional Ethics Committee of Pasteur Institute of Iran (ethical code: IR.PII.REC. 1397.021).

\section{RESULTS}

\section{Experimental systemic and oral candidiasis}

The present study was designed to evaluate the virulence activity of the $C$. albicans strains isolated from skin lesions to induce systemic and oral candidiasis in murine models. Eight $C$. albicans isolates were selected according to the highest and the lowest in vitro virulence activity in four clades derived from typing by MLST method ${ }^{[13]}$ (Fig. 1). Each of two isolates of separate minor clades showed different in vitro and in vivo pathogenicity, but there was no evident association between the strains in variant major clades and all studied forms of pathogenesis.

\section{SAP expression}

The primers used in real-time PCR assay are shown in Table 1. Each of the different $S A P$ primer sets were specified for each $S A P$ gene, excluding the possibility that any one $S A P$ primer set could cause a falsepositive result. We examined the expression of genes encoding Sap1-3 in eight $C$. albicans isolates. Each of the $S A P 1, S A P 2$, and $S A P 3$ genes was expressed in $50 \%, 100 \%$, and $75 \%$ of the strains, separately. Three patterns in the genotypes of SAP1-3 were identified. Four strains expressed all the studied $S A P$ genes, two isolates $S A P 2$ and 3 and two isolates only one. The folding changes $\left(2^{-\triangle \Delta C T}\right)$ of the SAP1-3 genes in all the isolates from different minor clades with their mean values are illustrated in Figure 2.

\section{Virulence factors}

Table 2 displays the in vitro virulence ability such as SAP expression, biofilm formation, phospholipase production, and pseudohyphae creation. The biofilm formation rates in $12 \%$ of the isolates were negative and in $38 \%$ high. Also, $50 \%$ of the strains had no phospholipase activity, and no one demonstrated the high level of this pathogen factor. Relatively, all the strains had low capability to form pseudohyphae.

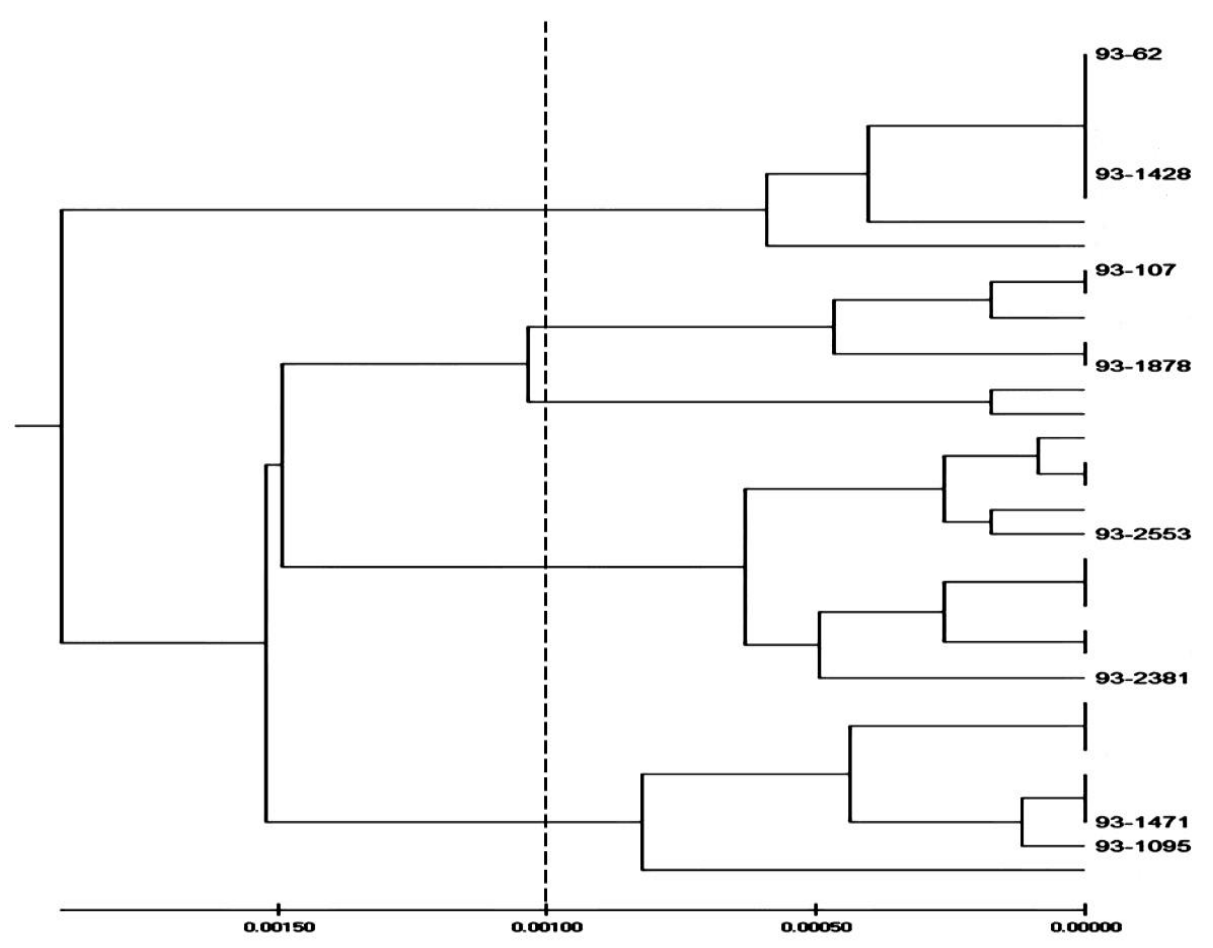

Fig. 1. The dendrogram constructed from UPGMA analysis based on concatenated MLST sequence of the seven loci of eight C. albicans strains. 

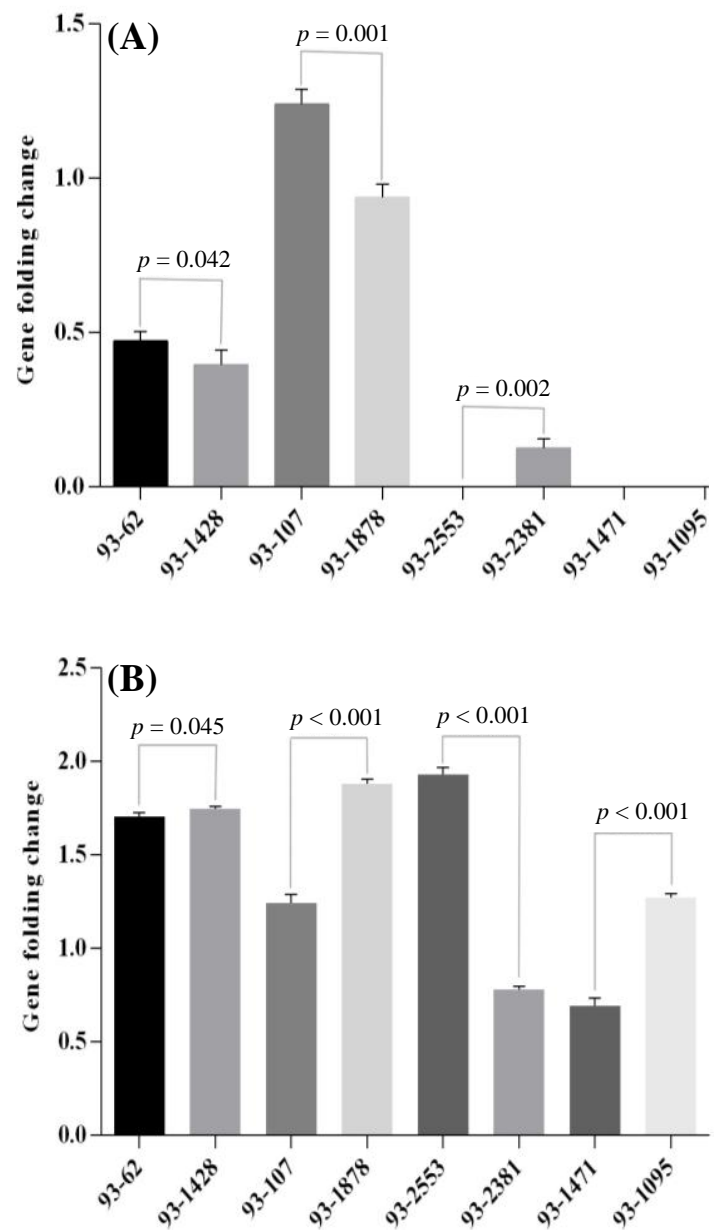
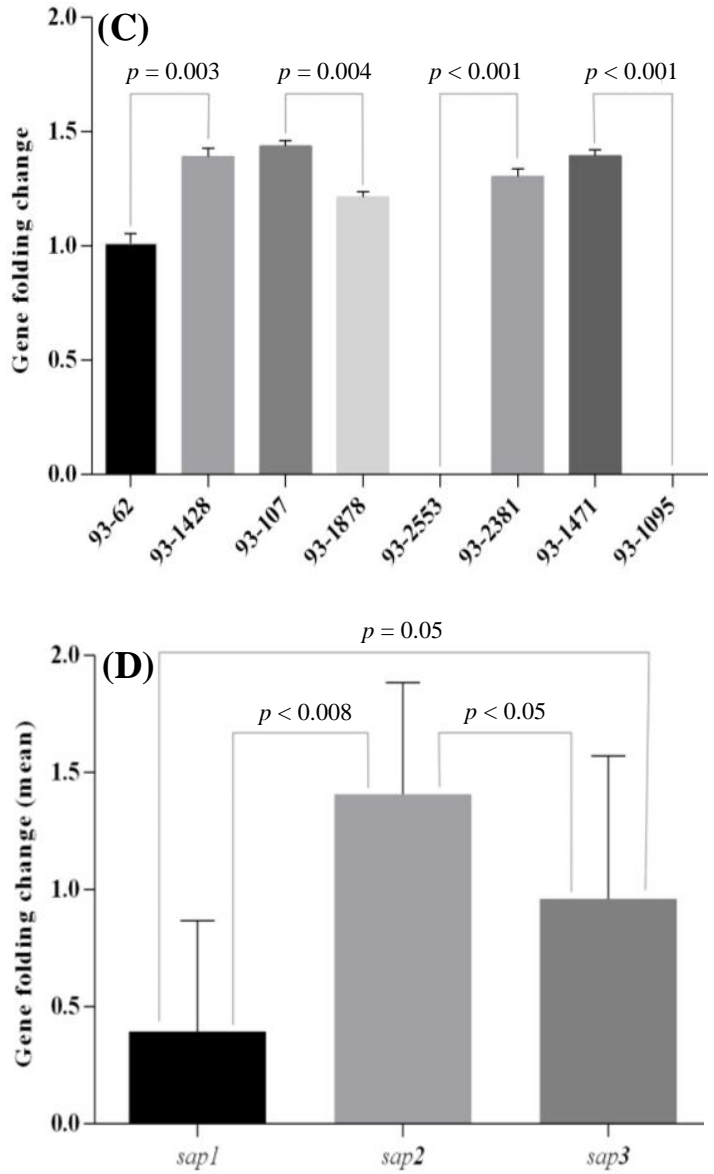

Fig. 2. Comparison of $S A P 1-3$ expression according to the folding change ( $2^{-\triangle \triangle C T}$ ) in eight $C$. albicans isolates. $S A P 1$ (A), SAP2 (B), $S A P 3$ (C), and the mean values of SAP1-3 expression (D).

\section{Histology in relation to virulence}

Weights of mice and organs, mortality, and in vivo pathogenicity in animals challenged with eight $C$. albicans isolates to form oral and systemic infections demonstrated in Table 3 were different. All of these strains isolated from patients suffering from cutaneous candidiasis with different pathogenic potential were able to cause systemic and oral candidiasis in mice. Histopathological analysis of kidneys and tongues, collected from BALB/c mice in which systemic and oral candidiasis were induced, showed different incidence of established infection and inflammation by C. albicans fitting to their in vivo pathogenesis, with abundant yeasts and the formation of pseudohyphae/ hyphae (Fig. 3).

\section{DISCUSSION}

Candida infections are one of the most significant nosocomial infections that have proliferated by 3.5 to
14 folds over the past decades. Although the sources of infection are human normal flora, hospital environments have an undisputable role ${ }^{[23]}$. During both superficial and systemic infection, C. albicans strains depend on a complex of virulence factors. It has been shown that the injury of host epithelial cells induced by filamentous forms (hyphae and pseudohyphae) of $C$. albicans is the main factor facilitates the growth and invasion of the fungus ${ }^{[24]}$.

Our results showed that in contrast to morphological transition, enzymatic activities were not involved in fungal pathogenesis. These findings are in accordance with the results of a previous study implying that a high percentage of phospholipase production (53.8$74 \%$ ) by $C$. albicans isolates ${ }^{[25]}$. In another study, authors showed that Candida isolates from candidemia has considerable phospholipase activity contributed to their virulence. Despite the known role of filamentous forms of C. albicans in fungal pathogenesis, yeast cells of the fungus were abundantly reported from infected tissues ${ }^{[26]}$. It has been demonstrated that biofilm- 
Table 2. In vitro pathogenicity in eight different $C$. albicans isolates

\begin{tabular}{|c|c|c|c|c|c|c|}
\hline \multirow{2}{*}{ No. } & \multicolumn{3}{|c|}{ SAP expression } & \multirow{2}{*}{ Biofilm $^{\text {a }}$} & \multirow{2}{*}{$\begin{array}{l}\text { Phospholipase } \\
\qquad\left(\mathbf{P}_{\mathbf{z}}\right)^{\mathbf{b}}\end{array}$} & \multirow{2}{*}{$\begin{array}{c}\text { Pseudohyphae } \\
(\%)^{\mathrm{c}}\end{array}$} \\
\hline & SAP1 & SAP2 & SAP3 & & & \\
\hline $93-62$ & + & + & + & +2 & 0.42 & 8 \\
\hline $93-1428$ & + & + & + & - & 1.00 & 5 \\
\hline 93-107 & - & + & + & +2 & 1.00 & 5 \\
\hline 93-1878 & + & + & + & +3 & 0.84 & 29 \\
\hline $93-2553$ & - & + & - & +1 & 1.00 & 4 \\
\hline $93-2381$ & - & + & + & +3 & 0.66 & 17 \\
\hline $93-1471$ & - & + & + & +2 & 1.00 & 6 \\
\hline $93-1095$ & - & + & - & +3 & 0.70 & 11 \\
\hline
\end{tabular}

(-) negative; ${ }^{\mathrm{a}} 1+, 2+$, and 3+: \% Tbloc (Measure of light blocked when passing through the wells) 5-20, 20-35, and 35-50, respectively. ${ }^{b} \mathrm{P}_{\mathrm{z}}=$ the diameters of the colonies (A) and the precipitation zone (B) around the colonies (medium: $\mathrm{Pz}=0.41-0.60$, low: $\mathrm{Pz}=0.61-0.80$, very low: $\mathrm{Pz}=0.81$ 0.99 , and none: $\mathrm{Pz}=1)$. ${ }^{\mathrm{c}}$ The percentage of cells in pseudohyphae form. Seven mice were challenged for each of the isolates.

forming ability was more frequent among bloodstream isolates than that of the isolates from other clinical sources ${ }^{[27]}$. Other virulence factors of $C$. albicans in oral candidiasis are closely related to molecular factors such as Saps, in particular Sap1-3, whereas in denture stomatitis, biofilm formation is the most important factor $^{[28]}$. To date, different roles are attributed to Saps (level of activity and number of SAP genes) of $C$. albicans in relation to pathogenesis, which mainly facilitate the fungal invasion and affect host immune responses ${ }^{[29]}$.
Our findings showed that each of the SAP1, SAP2, and SAP3 genes was expressed in 50\%, 100\%, and $75 \%$ of the strains, separately. SAP2 and 3 expressions in our study were similar to a previous report for $C$. albicans strains with oral and vaginal source by Dabiri et al. ${ }^{[18]}$ in Iran, whereas the result for $S A P I$ activity was different. According to a previous report by Lima et al. ${ }^{[30]}$, the SAPl gene had more expression in the process of vaginal infection in comparison to the oral infection. More investigation suggested that SAP1-3

Table 3. Weights of mice and organs, mortality, and in vivo pathogenicity in animals challenged with eight $C$. albicans isolates to form oral and systemic infections

\begin{tabular}{|c|c|c|c|c|c|c|c|c|}
\hline \multirow[t]{2}{*}{ No. } & \multicolumn{2}{|c|}{$\begin{array}{l}\text { Mouse weight change (g) } \\
\text { mean (range) }\end{array}$} & \multicolumn{2}{|c|}{$\begin{array}{l}\text { Organ weight }(\mathrm{g}) \\
\text { mean (range) }\end{array}$} & \multicolumn{2}{|c|}{$\begin{array}{l}\text { Mortality } \\
\text { (day) }\end{array}$} & \multicolumn{2}{|c|}{$\begin{array}{l}\text { In vivo pathogenicity } \\
\text { (Log CFU/g tissue) } \\
\text { (median) range }\end{array}$} \\
\hline & Systemic & Oral & Systemic & Oral & Systemic & Oral & Systemic & Oral \\
\hline $93-62$ & $\begin{array}{c}-3.9 \\
((-5.2)-(-2.4))\end{array}$ & $\begin{array}{c}-4.0 \\
((-5.3)-(-2.6))\end{array}$ & $\begin{array}{c}0.21 \\
(0.14-0.30)\end{array}$ & $\begin{array}{c}0.07 \\
(0.04-0.09)\end{array}$ & $2 / 7(5)$ & $0 / 7(0)$ & $\begin{array}{c}(4.43) \\
3.69-4.73\end{array}$ & $\begin{array}{c}(4.41) \\
2.95-5.26\end{array}$ \\
\hline $93-1428$ & $\begin{array}{c}-1.5 \\
((-2.5)-(-0.7))\end{array}$ & $\begin{array}{c}-4.2 \\
((-5.5)-(-2.8))\end{array}$ & $\begin{array}{c}0.20 \\
(0.12-0.28)\end{array}$ & $\begin{array}{c}0.07 \\
(0.05-0.10)\end{array}$ & $0 / 7(0)$ & $1 / 7(2)$ & $\begin{array}{c}(1.75) \\
1.03-2.78\end{array}$ & $\begin{array}{c}(4.73) \\
4.59-4.82\end{array}$ \\
\hline 93-107 & $\begin{array}{c}-1.0 \\
((-2.3)-(-0.2))\end{array}$ & $\begin{array}{c}-3.8 \\
((-5.6)-(-0.5))\end{array}$ & $\begin{array}{c}0.18 \\
(0.14-0.20)\end{array}$ & $\begin{array}{c}0.07 \\
(0.04-0.09)\end{array}$ & $1 / 7(7)$ & $0 / 7(0)$ & $\begin{array}{c}(2.67) \\
1.46-4.33\end{array}$ & $\begin{array}{c}(4.22) \\
3.87-4.55\end{array}$ \\
\hline $93-1878$ & $\begin{array}{c}-5.1 \\
((-7.2)-(-2.6))\end{array}$ & $\begin{array}{c}-4.2 \\
((-5.2)-(-3.1))\end{array}$ & $\begin{array}{c}0.20 \\
(0.16-0.24)\end{array}$ & $\begin{array}{c}0.07 \\
(0.05-0.10)\end{array}$ & $0 / 7(0)$ & $0 / 7(0)$ & $\begin{array}{c}(3.37) \\
2.39-4.35\end{array}$ & $\begin{array}{c}(4.72) \\
4.30-5.27\end{array}$ \\
\hline $93-2553$ & $\begin{array}{c}-3.9 \\
((-6.0)-(-0.3))\end{array}$ & $\begin{array}{c}-4.5 \\
((-5.5)-(-3.5))\end{array}$ & $\begin{array}{c}0.19 \\
(0.18-0.22)\end{array}$ & $\begin{array}{c}0.07 \\
(0.05-0.09)\end{array}$ & $1 / 7(5)$ & $0 / 7(0)$ & $\begin{array}{c}(3.89) \\
3.23-4.44\end{array}$ & $\begin{array}{c}(5.11) \\
4.13-5.68\end{array}$ \\
\hline $93-2381$ & $\begin{array}{c}-2.5 \\
((-4.3)-(-0.7))\end{array}$ & $\begin{array}{c}-4.1 \\
((-5.2)-(-2.8))\end{array}$ & $\begin{array}{c}0.19 \\
(0.14-0.22)\end{array}$ & $\begin{array}{c}0.08 \\
(0.03-0.11)\end{array}$ & $0 / 7(0)$ & $1 / 7(2)$ & $\begin{array}{c}(3.68) \\
1.93-4.97\end{array}$ & $\begin{array}{c}(4.81) \\
4.38-5.19\end{array}$ \\
\hline $93-1471$ & $\begin{array}{c}-5.2 \\
((-8.7)-(-3.3))\end{array}$ & $\begin{array}{c}-4.0 \\
((-5.3)-(-2.9)\end{array}$ & $\begin{array}{c}0.20 \\
(0.14-0 . .21)\end{array}$ & $\begin{array}{c}0.09 \\
(0.07-0.11)\end{array}$ & $0 / 7(0)$ & $0 / 7(0)$ & $\begin{array}{c}(3.59) \\
2.75-4.79\end{array}$ & $\begin{array}{c}(4.64) \\
4.32-5.29\end{array}$ \\
\hline 93-1095 & $\begin{array}{c}-4.4 \\
((-4.8)-(-3.5)) \\
\end{array}$ & $\begin{array}{c}-4.5 \\
((-5.3)-(-2.8)) \\
\end{array}$ & $\begin{array}{c}0.19 \\
(0.17-0.21) \\
\end{array}$ & $\begin{array}{c}0.09 \\
(0.07-0.10) \\
\end{array}$ & $1 / 7(5)$ & $0 / 7(0)$ & $\begin{array}{c}(3.75) \\
2.48-5.28 \\
\end{array}$ & $\begin{array}{c}(5.19) \\
4.98-5.54 \\
\end{array}$ \\
\hline
\end{tabular}



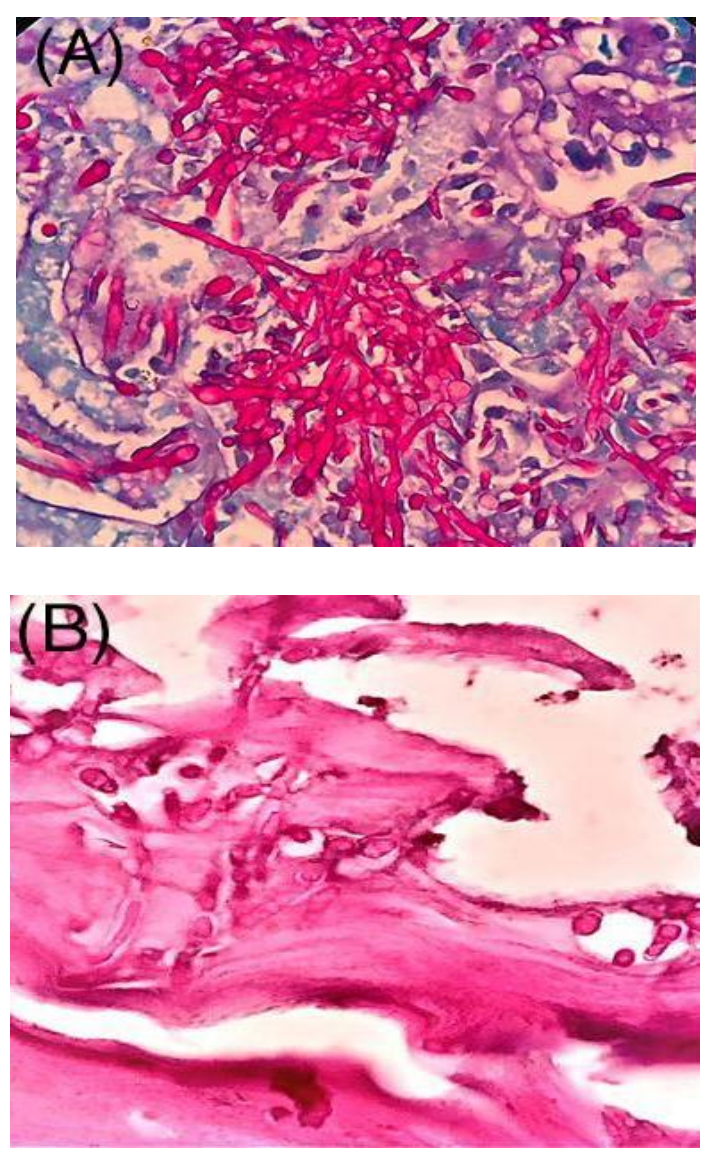

Fig. 3. Microscopic observation of typical lesions on the kidneys and tongues of mice with systemic and oral candidiasis on days 7 and 3 after the infection, respectively. Periodic acidSchiff-stained sections show the extensive colonization by numerous Candida hyphae in the kidney (A) and on the epithelium of the dorsal surface of the tongue $(B) .(\times 1000$ magnification)

appears to be essential for mucosal and SAP4-6 for systemic infections ${ }^{[31]}$. Our results demonstrated that the $S A P 2$ gene can be considered as an effective pathogenic factor for tissue destruction in oral candidiasis. As indicated in another investigation, $S A P 2$ gene may be a potential target for prevention or treatment of candidiasis ${ }^{[32]}$.

We have experimented oral and systemic models of candidiasis using $C$. albicans strains isolated from skin lesions and selected four clades derived from typing by MLST method ${ }^{[13]}$. The murine model that is considered as the "gold standard" in the study of oral and systemic Candida infections can be used to prove genetic determinants of Candida virulence ability ${ }^{[32]}$. Although the source of the fungal isolates may be a neglected confounding factor in virulence studies in animal models, in our study, all the isolated strains from patients with skin lesions were able to cause systemic and oral candidiasis in mice. Each of two isolates of separate minor clades demonstrated various degree of comparable pathogenicity, but there was no evident association between strains in variant major clades and all studied forms of pathogenesis. For instance, strains of 93-62 and 93-1428 in a minor clade clearly vary in a number of properties not exactly related to the particular gene sequences that are used to express their clade assignation. A similar report to our study was presented by MacCallum et al. ${ }^{[33]}$. It has been shown that phenotypic amendment in $C$. albicans changes gradually over the years as a result of small alterations in the sequences of some genes ${ }^{[34]}$. In agreement with Tavanti et al.'s ${ }^{[35]}$ report, the utility of MLST for determining clade assignments of clinical isolates will form a basis for the rational selection of a wider diversity of strains for future researches into $C$. albicans virulence. It is obvious that either fungal characteristics or host reactions determine the outcome of fungal infection and development of clinical manifestation. Although the importance of hypha production and phospholipase production in Candida pathogenicity is undisputed, the yeast can also disseminate and multiply in internal organs. Besides, our results, in a few isolates, indicated that other factors may account for the observed variation in the development of infection in animals (Table 2). Presumably, the ability to cause diseases in the mammalian host is the product of a combination of these phenotypes and others. This observation was similar to a previous report by Asmundsdóttir et al. ${ }^{[36]}$. Ideally, for meaningful comparison, many representative isolates should be used.

Taken together, our findings further indicate that virulence factors of $C$. albicans are important determinants of the outcome of Candida-related invasion in relation to phenotypic and genotypic characteristics. Inclusive comparative studies from different geographical areas of the world are highly recommended in order to make a global profile of virulence in $C$. albicans.

\section{ACKNOWLEDGMENTS}

This study was supported financially by a Ph.D. grant to Golnar Sadeghi and a research grant (no. 766) to Mahdi Razzaghi-Abyaneh by the Pasteur Institute of Iran, Tehran. Research reported in this publication was supported by Elite Researcher Grant Committee under award numbers 958634 and 963646 from the National Institute for Medical Research Development (NIMAD), Tehran, Iran.

CONFLICT OF INTEREST. None declared. 


\section{REFERENCES}

1. Ortega M, Marco F, Soriano A, Almela M, Martínez JA, López J, Pitart C, Mensa J. Candida species bloodstream infection: epidemiology and outcome in a single institution from 1991 to 2008. Journal of hospital infection 2011; 77(2): 157-161.

2. Razzaghi-Abyaneh M, Sadeghi G, Zeinali E, Alirezaee M, Shams-Ghahfarokhi M, Amani A, Mirahmadi R, Tolouei R. Species distribution and antifungal susceptibility of Candida spp. isolated from superficial candidiasis in outpatients in Iran. Journal de mycologie médicale 2014; 24(2): 43-50.

3. Yildirim M, Sahin I, Kucukbayrak A, Ozdemir D, Tevfik Yavuz M, Oksuz S, Cakir S. Hand carriage of Candida species and risk factors in hospital personnel. Mycoses 2007; 50(3): 189-192.

4. Kühbacher A, Burger-Kentischer A, and Rupp S. Interaction of Candida species with the skin. Microorganisms 2017; 5(32): doi: 10.3390/microorganisms5020032.

5. Pfaller MA, Diekema DJ. Epidemiology of invasive mycoses in North America. Critical reviews in microbiology 2010; 36(1): 1-53.

6. Mayer FL, Wilson D, Hube B. Candida albicans pathogenicity mechanisms. Virulence 2013; 4(2): 119128.

7. Rahman D, Mistry M, Thavaraj S, Challacombe SJ, and Naglik JR. Murine model of concurrent oral and vaginal Candida albicans colonization to study epithelial host pathogen interactions. Microbes and infection 2007; 9(5): 615-622.

8. MacCallum DM. Hosting infection: experimental models to assay Candida virulence. International journal of microbiology 2012; 2012: Article ID 363764.

9. Szabo EK and MacCallum DM. The contribution of Mouse models to our understanding of systemic candidiasis. FEMS microbiology letters 2011; 320(1): 18 .

10. Yu S, Li W, Liu X, Che J, Wu Y and Lu J. Distinct expression levels of $A L S, L I P$, and $S A P$ genes in Candida tropicalis with diverse virulent activities. Frontiers in microbiology 2016; 7: 1175.

11. Frenkel M, Mandelltat M, Alastruey-Izquierdo A, Mendlovic S, Semis R, and Segal E. Pathogenicity of Candida albicans isolates from bloodstream and mucosal candidiasis assessed in mice and Galleria mellonella. Journal de mycologie médicale 2016; 26(1): $1-8$.

12. Richardson JP, Ho J and Naglik JR. Candida-epithelial interactions. Journal of fungi 2018; 4(1): doi: 10.3390/ jof4010022.

13. Sadeghi G, Ebrahimi-Rad M, Shams-Ghahfarokhi M, Jahanshiri Z, Ardakani E, Eslamifar A, Mousavi SF, Razzaghi-Abyaneh M. Cutaneous candidiasis in TehranIran: From epidemiology to multilocus sequence types, virulence factors and antifungal susceptibility of etiologic Candida species. Iranian journal of microbiology 2019; 11(4): 267-279.

14. Lionakis MS, Lim JK, Lee CC, Murphy PM. Organ- specific innate immune responses in a mouse model of invasive candidiasis. Journal of innate immunity 2011; 3(2):180-199.

15. Wong SS, Kao RY, Yuen KY, Wang Y, Yang D, Samaranayake LP, Seneviratne CJ. In vitro and in vivo activity of a novel antifungal small molecule against Candida infections. PLoS one 2014; 9(1): e85836.

16. Conti HR, Huppler AR, Whibley N, Gaffen SL. Animal models for candidiasis. Current protocols in immunology 2014; 105(1): 19.6.1-19.6.17.

17. Monroy-Pérez E, Paniagua-Contreras GL, VacaPaniagua F, Negrete-Abascal E, Vaca S. SAP expression in Candida albicans strains isolated from Mexican patients with vaginal candidiasis. International journal of clinical medicine 2013; 4(1): 25-31.

18. Dabiri S, Shams-Ghahfarokhi M, Mehdi RazzaghiAbyaneh M. SAP(1-3) gene expression in high proteinase producer Candida species strains isolated from Iranian patients with different candidosis. Journal of pure and applied microbiology 2016; 10(3): 18911896.

19. Zago CE, Silva S, Sanitá PV, Borbugli PA, Dias CM, Lordello VB, Vergani CE. Dynamics of biofilm formation and the interaction between Candida albicans and methicillin-susceptible (MSSA) and -resistant Staphylococcus aureus (MRSA). PLoS one 2015; 10(4): doi: 10.1371/journal.pone.0123206.

20. Tsang CS, Chu FC, Leung WK, Jin LJ, Samaranayake LP, Siu SC. Phospholipase, proteinase and hemolytic activities of Candida albicans isolated from oral cavities of patients with type 2 diabetes mellitus. Journal of medical microbiology 2007; 56(Pt 10): 1393-1398.

21. Galán-Ladero MA, Blanco MT, Sacristán B, FernándezCalderón MC, Pérez-Giraldo C, Gómez-García AC. Enzymatic activities of Candida tropicalis isolated from hospitalized patients. Medical mycology 2010; 48(1): 207-210.

22. Negri M, Martins M, Henriques M, Svidzinski TIF, Azeredo J, Oliveira R. Examination of potential virulence factors of Candida tropicalis clinical isolates from hospitalized patients. Mycopathologia 2010; 169(3): 175-182.

23. Taghipour S, Rezaei-Matehkolaei A, Zarei Mahmoudabadi A. Antifungal susceptibility profiles of Candida species isolated from Ahvaz Jundishapur educational hospitals. Jundishapur journal of microbiology 2018; 11(11): e78851.

24. Nasution AI. Virulence factor and pathogenicity of Candida albicans in oral candidiasis. World journal of dentistry 2013; 4(4): 267-271.

25. Costa CR, Passos XS, Souza LK, Lucena PA, Fernandes Ode F, Silva Mdo R. Differences in exoenzyme production and adherence ability of Candida spp. isolates from catheter, blood and oral cavity. Revista do instituto de medicina tropical de são paulo 2010; 52(3): 139-143.

26. Wibawa T. The role of virulence factors in Candida albicans pathogenicity. Journal of medical science 2016; 48(1): 58-68.

27. Bruder-Nascimento A, Camargo CH, Mondelli AL, 
Fátima Sugizaki M, Sadatsune T, Bagagli E. Candida species biofilm and Candida albicans ALS3 polymorphisms in clinical isolates. Brazilian journal of microbiology 2014; 45(4): 1371-1377.

28. Jabra-Rizk MA, Kong EF, Tsui C, Nguyen MH, Clancy CJ, Fidel PL Jr, Noverr M. Candida albicans pathogenesis: fitting within the host-microbe damage response framework. Infection and immunity 2016; 84(10): 2724- 2739.

29. Staniszewska M, Bondaryk M, Siennicka K, Piłat J, Schaller M, Kurzątkowski W. Role of aspartic proteinases in Candida albicans virulence. PART II: Expression of SAP 1-10 aspartic proteinase during Candida albicans infection in vivo. Postepy Mikrobiologii 2012; 51 (2): 127-135.

30. Lima JS, Braga KRGS, Vieira CA, R. Souza WWR, Chávez-Pavoni JH, de Araújo C, Goulart LS. Genotypic analysis of secreted aspartyl proteinases in vaginal Candida albicans isolates. Jornal brasileiro de patologia e medicina laboratorial 2018; 54(1): 28-33.

31. Taylor BN, Staib P, Binder A, Biesemeier A, Sehnal M, Röllinghoff M, Morschhäuser J, Schröppel K. Profile of Candida albicans-secreted aspartic proteinase elicited during vaginal infection. Infection and immunity 2005; 73(3): $1828-1835$.
32. Chin VK, Lee TY, Rusliza B, Chong PP. Dissecting Candida albicans infection from the perspective of $C$. albicans virulence and omics approaches on hostpathogen interaction: a review. International journal of molecular science 2016; 17(10): E1643.

33. MacCallum DM, Castillo L, Nather K, Munro CA, Brown AJ, Gow NA, Odds FC. Property differences

among the four major Candida albicans strain clades. Eukaryotic cell 2009; 8(3): 373-387.

34. Odds FC, Jacobsen MD. Multilocus sequence typing of pathogenic Candida species. Eukaryotic cell 2008; 7(7): 1075-1084

35. Tavanti A, Davidson AD, Mark J. Fordyce MJ, Gow NAR, Maiden MC, and Odds FC. Population structure and properties of Candida albicans, as determined by multilocus sequence typing. Journal of clinical microbiology 2005; 43(11): 5601-5613.

36. Asmundsdóttir LR, Erlendsdóttir H, Agnarsson BA, Gottfredsson M. The importance of strain variation in virulence of Candida dubliniensis and Candida albicans: results of a blinded histopathological study of invasive candidiasis. Clinical microbiology and infection 2009; 15(6): 576-585. 